\title{
Formation of intermetallic phases during solidification in Al-Mg- Mn 5xxx alloys with various Mg levels
}

\author{
Ahmed Y. Algendy ${ }^{1}$, Kun Liu ${ }^{1 *}$, X.-Grant Chen ${ }^{1}$ \\ ${ }^{1}$ Department of Applied Science, University of Quebec at Chicoutimi, Saguenay (QC), Canada
}

\begin{abstract}
In the present study, four Al-Mg-Mn 5xxx alloys with different Mg levels (2-5 wt.\%) were investigated for better understanding the evolution of intermetallic phases formed during solidification. Optical and scanning electron microscopes, electron backscattered diffraction and differential scanning calorimetry analyses in combination with thermodynamic calculation were used to identify various intermetallic phases. Results showed that the most dominant intermetallic phases are $\mathrm{Al}_{6}(\mathrm{Mn}, \mathrm{Fe}), \alpha-\mathrm{Al}(\mathrm{Fe}, \mathrm{Mn}) \mathrm{Si}, \mathrm{Al}_{3} \mathrm{Fe}, \mathrm{Al}_{\mathrm{m}}(\mathrm{Mn}, \mathrm{Fe})$ and $\mathrm{Mg}_{2} \mathrm{Si}$ in experimental $\mathrm{Al}-\mathrm{Mg}-\mathrm{Mn}$ alloys, which is greatly dependant on the Mg levels. It is found that Chinese script $\alpha-\mathrm{Al}(\mathrm{Fe}, \mathrm{Mn}) \mathrm{Si}$ is the dominant iron-rich intermetallic phase for the alloys containing 2-3 wt.\% $\mathrm{Mg}$, while blocky $\mathrm{Al}_{6}(\mathrm{Mn}, \mathrm{Fe})$ and needle-like $\mathrm{Al}_{3}(\mathrm{Mn}, \mathrm{Fe})$ become the major phases for the alloy containing 4 wt.\% Mg. Further increasing $\mathrm{Mg}$ content to 5 wt. \%, the dominant phase transfers to blocky $\mathrm{Al}_{6}(\mathrm{Mn}, \mathrm{Fe})$ intermetallic. Meanwhile, the morphology of primary $\mathrm{Mg}_{2} \mathrm{Si}$ is changed from well-branched to plate-like with increasing $\mathrm{Mg}$ contents. In addition, $\beta-\mathrm{Al}_{3} \mathrm{Mg}_{2}$ and $\tau-\mathrm{Al}_{6} \mathrm{CuMg}_{4}$ eutectic phases have been observed in the alloys with 3-5 wt. \% Mg. A comparison on various intermetallic phases from the Scheil simulation and the actual ascast microstructure is provided.
\end{abstract}

Keywords: Al-Mg 5xxx alloys; Intermetallic phases; $\mathrm{Mg}_{2} \mathrm{Si}$; Solidification.

\section{Introduction}

Commercial Al-Mg-Mn 5xxx wrought alloys offer an attractive combination of high strength, good formability, weldability and excellent corrosion resistance, making them suitable for a wide spectrum of applications, such as structures, automotive industries and marine applications. [1-2]. During the design and manufacture processes of $5 \mathrm{xxx}$ alloys, the microstructure plays a significant role on the alloy properties, especially the type and distribution of intermetallic phases formed during solidification, which can be greatly affected by chemical compositions. Various researches have been performed to investigate the microstructure and phase identification during the solidification in $5 \times x x$ aluminum alloys. The main intermetallic phases formed during solidification of this series were reported to be $\mathrm{Al}_{6}(\mathrm{Mn}, \mathrm{Fe}), \alpha-\mathrm{Al}(\mathrm{Fe}, \mathrm{Mn}) \mathrm{Si}$, $\mathrm{Al}_{3} \mathrm{Fe}$ and $\mathrm{Al}_{\mathrm{m}}(\mathrm{Mn}, \mathrm{Fe})$ [3-11]. Alloys with $3 \% \mathrm{Mg}$ content or higher display the formation of $\beta-\mathrm{Al}_{5} \mathrm{Mg}_{3}$ or $\tau-\mathrm{Al}_{6} \mathrm{CuMg}_{4}$ [3]. Simensen et al. [4] proposed that the main intermetallic phases formed during solidification of Al-Mg-Mn AA5182 alloy are $\mathrm{Al}_{6}(\mathrm{Mn}, \mathrm{Fe}), \mathrm{Al}_{3}(\mathrm{Mn}, \mathrm{Fe}, \mathrm{Cu}), \mathrm{Al}_{8}(\mathrm{Mg}, \mathrm{Cu})_{5}$, and $\mathrm{Mg}_{2} \mathrm{Si}$, while it is reported that the dominant iron-bearing particles are $\mathrm{Al}_{\mathrm{m}}(\mathrm{Fe}, \mathrm{Mn})$ and $\mathrm{Al}_{3}(\mathrm{Fe}, \mathrm{Mn})$ instead of $\mathrm{Al}_{6}(\mathrm{Fe}$, $\mathrm{Mn})$ and $\mathrm{Al}_{3}(\mathrm{Fe}, \mathrm{Mn})$ [5]. Engler et al. reported [8] that the as-cast microstructure of AA5454 alloy consists of two major different types of constituents $\mathrm{Al}_{6}(\mathrm{Fe}, \mathrm{Mn})$ and $\mathrm{Mg}_{2} \mathrm{Si}$ with occasionally observed eutectic $\beta-\mathrm{Al}_{5} \mathrm{Mg}_{3}$. The solidified microstructure of AA5083 alloy is found to be composed of two main iron-rich phases, which are $\mathrm{Al}_{6}(\mathrm{Mn}, \mathrm{Fe}), \alpha-\mathrm{Al}(\mathrm{Fe}, \mathrm{Mn}) \mathrm{Si}$ with minor $\varepsilon-\mathrm{Al}_{18}(\mathrm{Cr}, \mathrm{Mn})_{2} \mathrm{Mg}_{3}$ and eutectic $\beta-\mathrm{Al}_{5} \mathrm{Mg}_{3}$ or $\tau-\mathrm{Al}_{6} \mathrm{CuMg}_{4}$ [6]. Studies showed that the dominant Fe-rich phases of the as-cast AA5754 alloy are changed to $\mathrm{Al}_{3}(\mathrm{Fe}, \mathrm{Mn})$ and $\alpha-\mathrm{Al}(\mathrm{Fe}, \mathrm{Mn}) \mathrm{Si}$, and only $\mathrm{Al}_{3}(\mathrm{Fe}, \mathrm{Mn})$ phase with $\mathrm{Fe}: \mathrm{Mn}$ ratio of about 5 in AA5182 alloy [7, 10]. However, most of literatures focused on the alloys with a high $\mathrm{Mg}$ range (4-5\%), such as 5083, 5182 and 5457 alloys, and there are also controversies on the formation of different intermetallic phases.

Therefore, it is important to better understand the formation of various intermetallic phases formed during solidification in Al-Mg-Mn 5xxx alloys, especially at a wider range of $\mathrm{Mg}$ levels. In this study, the formation of intermetallic phases in Al-Mg-Mn 5xxx with various $\mathrm{Mg}$ contents (2-5 wt.\%) were systematically studied, focusing on the identification and characterization using the combined analytic methods of optical microscope (OM), scanning electron microscope (SEM) equipped with an energy dispersive X-ray spectrometer (EDS) and electron backscattered diffraction (EBSD).

\section{Methodology}

Four experimental Al-Mg-Mn alloys with different $\mathrm{Mg}$ levels were prepared with commercial pure $\mathrm{Al}$ (99.8 wt.\%), pure $\mathrm{Mg}$ (99.9 wt.\%), Al-50 wt.\% Si, Al-50 wt.\% Cu, Al-25 wt.\% Mn, Al-25 wt.\% Fe, Al-20 wt.\% Cr, and Al-5wt.\%Ti1wt.\%B master alloys. Their chemical compositions

${ }^{*}$ Corresponding author: kun.liu@uqac.ca 
analyzed using an optical emission spectrometer are shown in Table 1. For each batch, approx. $3 \mathrm{~kg}$ of material was melted in clay-graphite crucible in an electric resistance furnace. The temperature was maintained at $780{ }^{\circ} \mathrm{C}$ for 30 min after melting followed by degassing for $15 \mathrm{~min}$. Then the melt was poured into a permanent steel mold preheated at $250{ }^{\circ} \mathrm{C}$. The dimensions of the cast ingots were $30 \mathrm{~mm} \times$ $40 \mathrm{~mm} \times 80 \mathrm{~mm}$.

Table 1: Chemical Compositions of Experimental Alloys

\begin{tabular}{|l|c|c|c|c|c|c|c|}
\hline \multirow{2}{*}{ Alloys } & \multicolumn{7}{|c|}{ Elements, wt.\% } \\
\cline { 2 - 8 } & $\mathbf{M g}$ & $\mathbf{M n}$ & $\mathbf{S i}$ & $\mathbf{F e}$ & $\mathbf{C u}$ & $\mathbf{C r}$ & $\mathbf{T i}$ \\
\hline M2 & $\mathbf{2}$ & 0.81 & 0.28 & 0.3 & 0.1 & 0.15 & 0.09 \\
\hline M3 & $\mathbf{3 . 3}$ & 0.81 & 0.28 & 0.25 & 0.1 & 0.16 & 0.09 \\
\hline M4 & $\mathbf{4}$ & 0.85 & 0.26 & 0.29 & 0.1 & 0.17 & 0.06 \\
\hline M5 & $\mathbf{5 . 2}$ & 0.78 & 0.26 & 0.31 & 0.1 & 0.18 & 0.1 \\
\hline
\end{tabular}

After casting, the samples were taken from the center of the ingot, grinded and polished. OM, SEM with EDS as well as EBSD and the Channel 5 software were used to identify various intermetallic phases formed during solidification. Meanwhile, Thermo-Calc software was used to predict the intermetallic phases formation as a function of $\mathrm{Mg}$ contents in both the equilibrium and non equilibrium states, while a Differential Scanning Calorimeter (DSC, Perkin Elmer DSC 8000) was used to confirm the intermetallic formation. DSC samples were taken from the as-cast ingot and heated with a heating rate of $10{ }^{\circ} \mathrm{C} / \mathrm{min}$ up to $750{ }^{\circ} \mathrm{C}$.

\section{Results and discussion}

\subsection{Thermo-Calc simulation}

The phase diagram calculated from Thermo-Calc as a function of $\mathrm{Mg}$ contents with the actual chemical compositions of experimental alloys is shown in Fig. 1a. It can be observed that the most important intermetallic constituents involve $\mathrm{Al}_{7} \mathrm{Cr}, \mathrm{Al}_{6} \mathrm{Mn}, \alpha-\mathrm{Al}(\mathrm{Fe}, \mathrm{Mn}) \mathrm{Si}$ and $\mathrm{Mg}_{2} \mathrm{Si}$ at the equilibrium condition. The dominant Fe-rich intermetallic phase at the low $\mathrm{Mg}$ level is $\alpha-\mathrm{Al}(\mathrm{Fe}, \mathrm{Mn}) \mathrm{Si}$ $\left(\mathrm{Al}_{15} \mathrm{Si}_{2} \mathrm{M}_{4}\right)$, while it is transferred to $\mathrm{Al}_{6} \mathrm{Mn}$ with increasing $\mathrm{Mg}$ level. In addition, $\tau$-phase $\left(\mathrm{Al}_{6} \mathrm{CuMg}_{4}\right)$ and $\beta$-phase $\left(\mathrm{Al}_{5} \mathrm{Mg}_{3}\right)$ can be formed at relatively low temperature. In order to simulate the non-equilibrium solidification, which is closer to our experiment condition, the solidification paths of four alloys are simulated with Scheil model, and the results of two alloys with $2 \% \mathrm{Mg}$ (M2) and 5\% Mg (M5) are shown in Fig. 1b and c. The Scheil simulations indicate the formation sequence of different types of intermetallic phases during solidification, including $\mathrm{Al}_{7} \mathrm{Cr}, \mathrm{Al}_{6} \mathrm{Mn}, \mathrm{Al}_{3} \mathrm{Fe}$ $\left(\mathrm{Al}_{13} \mathrm{Fe}_{4}\right), \mathrm{Mg}_{2} \mathrm{Si}$ and finally, $\tau$-phase and $\beta$-phase. As shown in Fig. $1 \mathrm{~b}$ and $\mathrm{c}$, increasing the $\mathrm{Mg}$ content not only affect the formation temperature of intermetallic phases but also change the type and sequence of phases.

In M2 alloy (Fig. 1b), the solidification starts at $648^{\circ} \mathrm{C}$ by the formation of $\alpha$-Al dendrites (Reaction 1). Afterwards, $\mathrm{Al}_{6} \mathrm{Mn}$ phase precipitates at $637{ }^{\circ} \mathrm{C}$ (Reaction 2) as $\alpha$-Al dendrites continue to grow. Similarly, $\mathrm{Al}_{3} \mathrm{Fe}\left(\mathrm{Al}_{13} \mathrm{Fe}_{4}\right)$ and $\alpha-\mathrm{Al}(\mathrm{Fe}, \mathrm{Mn}) \mathrm{Si}\left(\mathrm{Al}_{15} \mathrm{Si}_{2} \mathrm{M}_{4}\right)$ phases start to precipitate at $608{ }^{\circ} \mathrm{C}$ and $604{ }^{\circ} \mathrm{C}$ (Reaction 3 and 4), respectively, followed by the precipitation of $\mathrm{Mg}_{2} \mathrm{Si}$ at $580{ }^{\circ} \mathrm{C}$ (Reaction $5)$. At the near end of the solidification $\tau$-phase (Reaction 7) may occur. On the other hand, in M5 alloy (Fig. 1c), the solidification starts by the precipitation of primary metastable $\mathrm{Al}_{7} \mathrm{Cr}$ phase at temperature of $670{ }^{\circ} \mathrm{C}$ (Reaction 1) followed by the formation of $\alpha$-Al dendrites (Reaction 2). $\mathrm{Al}_{6} \mathrm{Mn}$ phase precipitates with decreasing temperature at $628{ }^{\circ} \mathrm{C}$ (Reaction 3) as the growth of $\alpha$-Al dendrites continues, while the primary metastable $\mathrm{Al}_{7} \mathrm{Cr}$ formed at higher temperature disappears with decreasing the solidification temperature. Afterwards, the precipitations of $\mathrm{Al}_{3} \mathrm{Fe}\left(\mathrm{Al}_{13} \mathrm{Fe}_{4}\right)$ (Reaction 4) and $\mathrm{Mg}_{2} \mathrm{Si}$ (Reaction 5) occur at $590{ }^{\circ} \mathrm{C}$ and $565{ }^{\circ} \mathrm{C}$, respectively. Low-melting point $\tau$ phase (Reaction 6) and $\beta$-phase (Reaction 7) appear at relatively low temperatures of $452{ }^{\circ} \mathrm{C}$ and $446{ }^{\circ} \mathrm{C}$, respectively. Therefore, it can be found that $\mathrm{Mg}$ level has influence on the formation of intermetallic. It is observed that $\mathrm{Al}_{6} \mathrm{Mn}, \mathrm{Al}_{3} \mathrm{Fe}\left(\mathrm{Al}_{13} \mathrm{Fe}_{4}\right)$ and $\alpha-\mathrm{Al}(\mathrm{Fe}, \mathrm{Mn}) \mathrm{Si}\left(\mathrm{Al}_{15} \mathrm{Si}_{2} \mathrm{M}_{4}\right)$ are the main Fe-rich phases for M2 alloy as shown in Fig. 1b, while $\mathrm{Al}_{6} \mathrm{Mn}$ and $\mathrm{Al}_{3} \mathrm{Fe}\left(\mathrm{Al}_{13} \mathrm{Fe}_{4}\right)$ are important $\mathrm{Fe}$-rich phases with increasing Mg content (M5 alloy Fig. 1c).

Fig. 2 shows the results of the thermodynamic simulations (Scheil model) in the form of the mass fraction of the stable phases as a function of temperature of alloys M2 and M5. It indicated that $\mathrm{Al}_{6}(\mathrm{Mn}, \mathrm{Fe})$ formed as a major phase in both alloys. Further decrease the temperature a minor fraction of $\mathrm{Al}_{13} \mathrm{Fe}_{4}\left(\mathrm{Al}_{3} \mathrm{Fe}\right)$ and $\mathrm{Mg}_{2} \mathrm{Si}$ start to form. Alloy M5, (Fig. 2b) shows the formation of $\beta$-phase at temperature below $446{ }^{\circ} \mathrm{C}$ where the solubility limit of $\mathrm{Mg}$ is reached. Notably, at relatively low temperature, the software accuracy lost, explaining the sharp increase of $\beta$-phase in alloy M5 at $446{ }^{\circ} \mathrm{C}$. The majority and minority phases of experimental alloys compared with simulated results will be discussed later. 


\subsection{Intermetallic phases in the as-cast structure}

As shown in Figs 1-2, a variety of intermetallic phases existed in Al-Mg-Mn alloys, therefore all intermetallic phases formed during solidification of the experimental alloys are examined and identified. Fig. 3 shows the as-cast microstructure of M2 alloy containing $2 \% \mathrm{Mg}$, which is consisted of $\alpha$-Al dendrites as the matrix surrounded by two intermetallic phases with different morphology and contrast (Fig. 3a). Intermetallic particles that appear grey in the SEM (Fig. 3b) seem to contain heavy elements such as Fe, Mn and $\mathrm{Cr}$, while the phase containing light elements such as $\mathrm{Mg}$ and Si displays dark. SEM-EDS analysis has been employed to verify the chemical compositions of different phases and the results are shown in Table 2. The majority of intermetallic phases with Chinese script morphology is $\alpha$ $\mathrm{Al}(\mathrm{Fe}, \mathrm{Cr}, \mathrm{Mn}) \mathrm{Si}$ (see the marks of a1 and a2), while the dark branched phase is identified as $\mathrm{Mg}_{2} \mathrm{Si}$ (marked as a3).

Fig. 4 displays the distribution of intermetallics in M3 alloy containing $3.3 \% \mathrm{Mg}$. Three different intermetallic constituents with different contrast are observed, as shown in Fig. 4a and 4b. The irregular bright phase is identified as $\alpha-\mathrm{Al}(\mathrm{Fe}, \mathrm{Mn}) \mathrm{Si}$ (marked as b1), while the grayish particles contain higher amount of $\mathrm{Cu}$ and $\mathrm{Mg}$ is classified as $\tau$ $\mathrm{Al}_{6} \mathrm{CuMg}_{4}$ (see b2) [6-8], which is often found to be close to the black intermetallic $\mathrm{Mg}_{2} \mathrm{Si}$ (see b3).

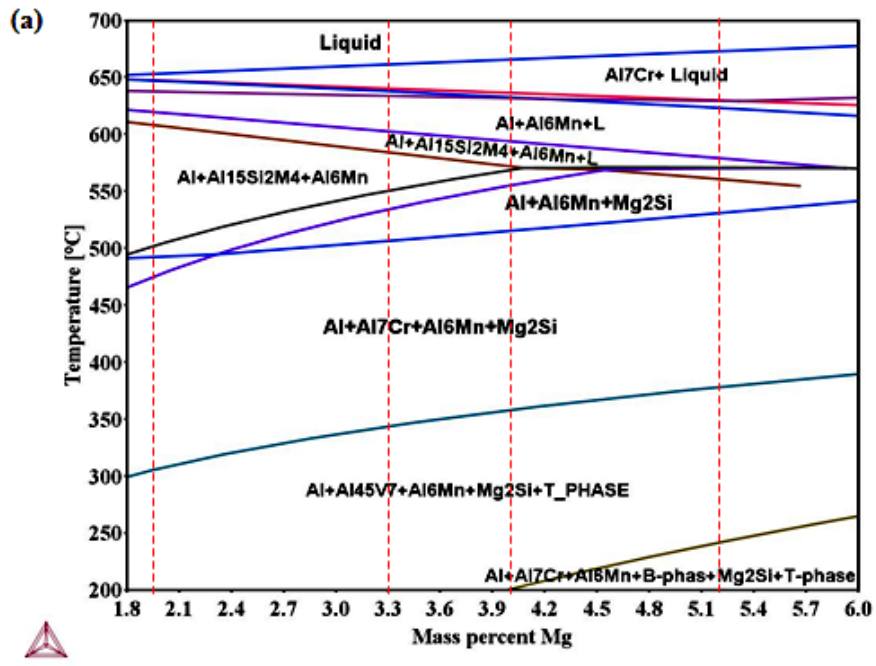

(b)

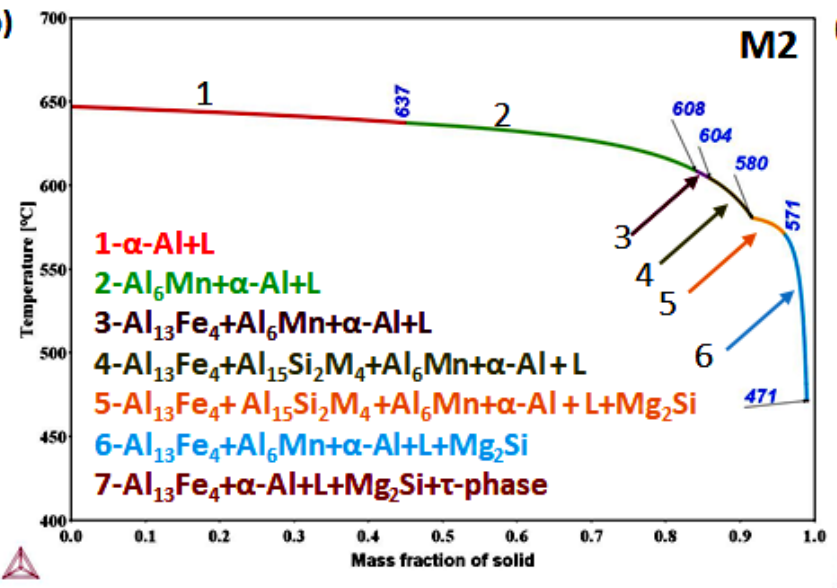

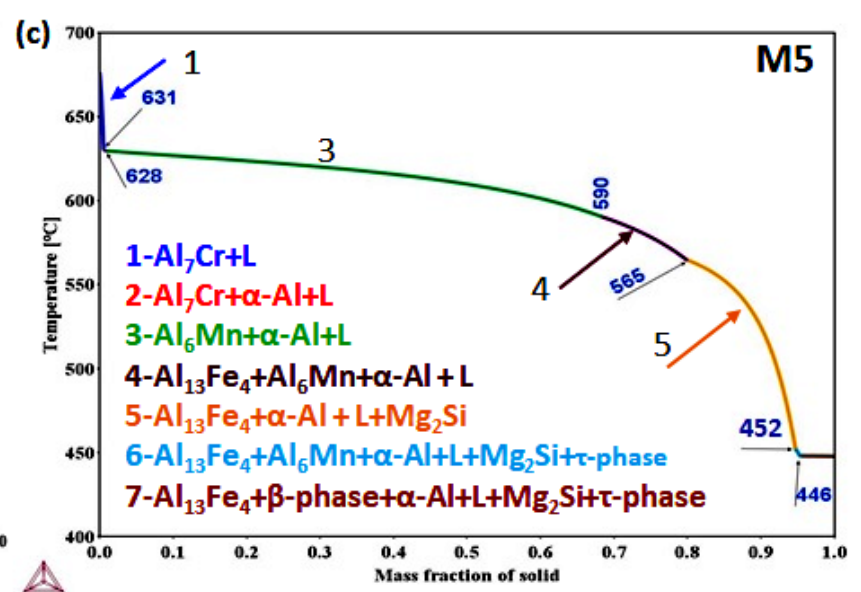

Fig. 1. Thermodynamic simulation for Al-Mg 5xxx alloys (a) The equilibrium phase diagram of Al-Mg-Mn alloy and (b and c) Scheil simulations showing the solidification sequence of different phases for M2 (b) and M5 (c) alloys. 

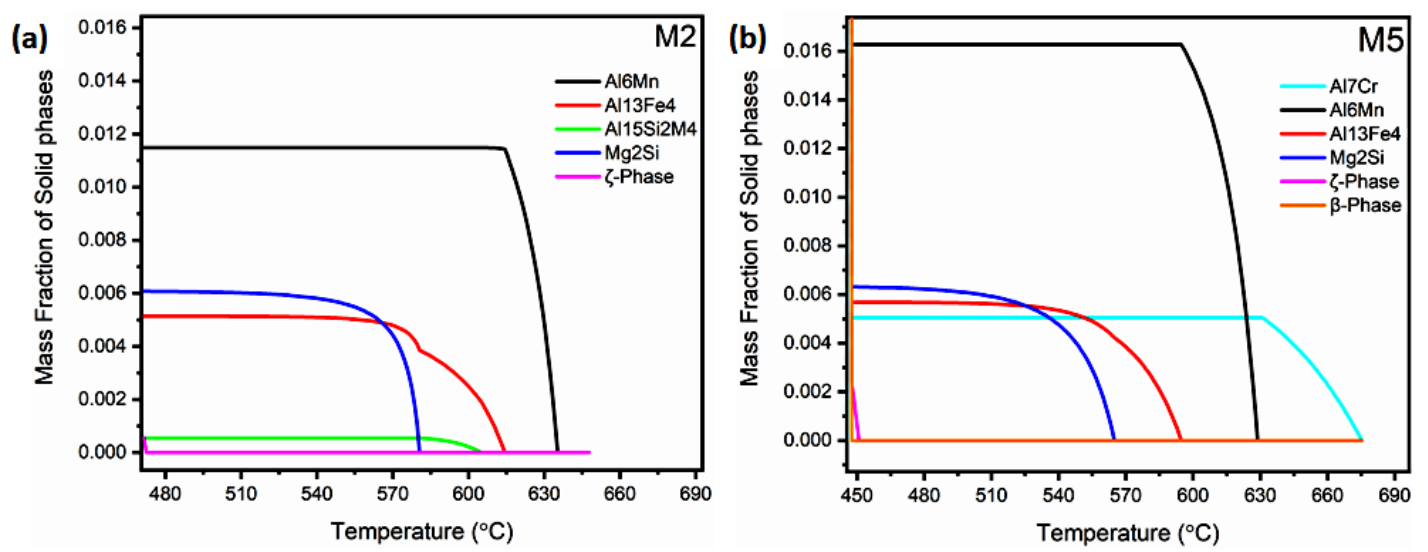

Fig. 2. Thermodynamic simulation from scheil model showing the mass fraction of different phases as a function of temperature of alloys M2 and M5.
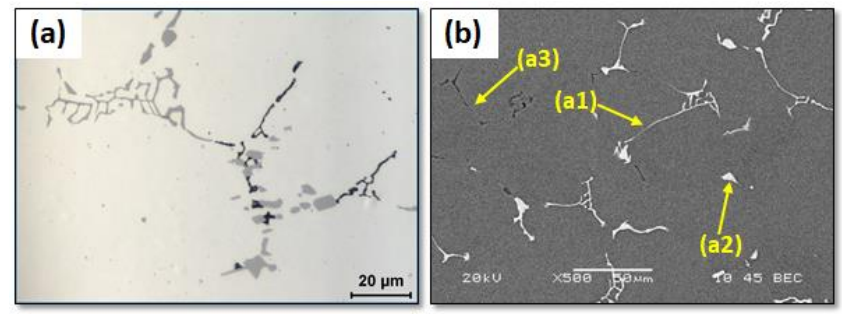

Fig. 3. As-cast microstructure of M2 alloy
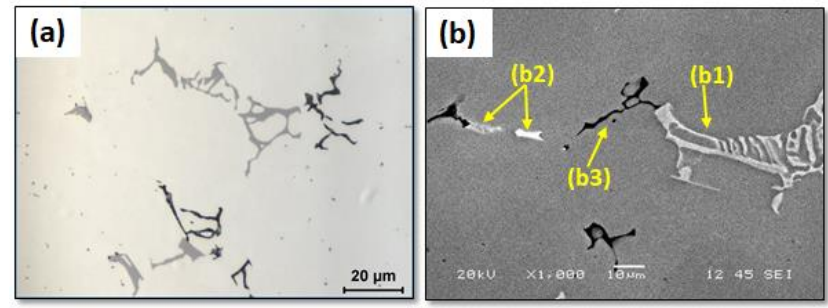

Fig. 4. As-cast microstructure of M3 alloy

The as-cast microstructure of M4 alloy containing 4\% $\mathrm{Mg}$ is shown in Fig. 5, which is quite different with M2 and M3 alloys. Two needle-like phases with two different color (gray and dark) are observed in Fig. 5a together with a Chinese script phase and blocky phase. SEM images of Fig. 5b-e show the details of typical intermetallics observed in M4 alloy. The bulky bright particles in Fig. 5b are found to be comprised of $\mathrm{Mn}$ and $\mathrm{Fe}$ without $\mathrm{Si}$, which can be classified as $\mathrm{Al}_{6}(\mathrm{Mn}, \mathrm{Fe})$ phase (marked as $\left.\mathrm{c} 1\right)$. Intermetallic particles that exhibit branched and Chinese script morphology with higher $\mathrm{Si}$ are identified as $\alpha-\mathrm{Al}(\mathrm{Fe}, \mathrm{Mn}) \mathrm{Si}$ (marked as c2). These two phases are further confirmed by the EBSD analysis (shown later) since their morphology are similar but with different crystal structure $[7,13]$.
Furthermore, the lighter phase with elongated long rodshape was observed to be comprised of $\mathrm{Mn}$ and $\mathrm{Fe}$ but free of $\mathrm{Si}$, and it is identified as $\mathrm{Al}_{3}(\mathrm{Mn}, \mathrm{Fe}$ ) (see c3). Occasionally, a minor Cr-rich phase with blocky shape were detected with high $\mathrm{Mn}, \mathrm{Cr}$ and $\mathrm{Mg}$ contents but without $\mathrm{Fe}$ and $\mathrm{Si}$, which is identified as $\varepsilon-\mathrm{Al}_{18}(\mathrm{Cr}, \mathrm{Mn})_{2} \mathrm{Mg}_{3}$ (see c4). The other grayish intermetallic contains high amount of $\mathrm{Cu}$ and $\mathrm{Mg}$ may be classified as $\tau-\mathrm{Al}_{6} \mathrm{CuMg}_{4}$ (see c5), while the dark particles observed with needle, flakes-like morphology are characterized as $\mathrm{Mg}_{2} \mathrm{Si}$ (marked as c6).

The as-cast microstructure of M5 alloy is shown in Fig. 6. The major grey particles containing $\mathrm{Mn}$ and Fe but without $\mathrm{Si}$ with compacted morphology are proposed to be $\mathrm{Al}_{6}(\mathrm{Mn}, \mathrm{Fe})$ and $\mathrm{Al}_{\mathrm{m}}(\mathrm{Mn}, \mathrm{Fe})$ (marked as $\left.\mathrm{d} 1\right)$, more details on these two phases will be discussed later using EBSD analysis. A minor irregular Fe-rich phase with high $\mathrm{Si}$ is found to be $\alpha-\mathrm{Al}(\mathrm{Fe}, \mathrm{Mn}) \mathrm{Si}$ (marked as $\mathrm{d} 2$ ). Occasionally, a $\mathrm{Cr}$-rich phase with blocky shape is detected with relatively high $\mathrm{Mn}, \mathrm{Cr}$ and $\mathrm{Mg}$ content but without $\mathrm{Fe}$ and $\mathrm{Si}$, which is identified as $\varepsilon-\mathrm{Al}_{18}(\mathrm{Cr}, \mathrm{Mn})_{2} \mathrm{Mg}_{3}$ (see. $\mathrm{d} 3$ ). In addition, bright/grayish phase is found to be close to $\mathrm{Mg}_{2} \mathrm{Si}$ with high $\mathrm{Cu}$ and $\mathrm{Mg}$, which can be classified as $\mathrm{Cu}$-containing eutectic phase $\tau-\mathrm{Al}_{6} \mathrm{CuMg}_{4}$ (see d4). Occasionally, a minor grey phase with rod shapes is observed to have high $\mathrm{Cr}$ and Ti and it is believed to be $\mathrm{Al}_{7}(\mathrm{Cr}, \mathrm{Ti})$ (see d6), which formed as a primary phase at the beginning of solidification at relatively high temperature (Reaction 1 in Fig. 1c). Finally, the dark phases with plate-like morphology are characterised as $\mathrm{Mg}_{2} \mathrm{Si}$ (see d5).

As shown in Figs. 3-6 the formation of low eutectic phases $\beta-\mathrm{Al}_{5} \mathrm{Mg}_{3}$ or $\tau-\mathrm{Al}_{6} \mathrm{CuMg}_{4}$ can be observed in the alloys with $3 \% \mathrm{Mg}$ content or higher, such as M5 in Fig. 6. Besides, various $\mathrm{Fe}$-rich intermetallics are observed in 
experimental alloys. In the present study, DSC is further applied to confirm the formation of various intermetallic phases. As shown in Fig. 7 (Peak 1), a small exothermic peak is observed in the temperature range $447-449{ }^{\circ} \mathrm{C}$, which is in the same range of $\beta$-phase formation [3] for alloy containing $5 \% \mathrm{Mg}$ content. On the other hand, there is no peak detected in alloy with lower $\mathrm{Mg}$ (i.e. $2 \% \mathrm{Mg}$ ). Notably in Fig 1c, the simulation results for the formation temperatures of $\tau$-and $\beta$-phases are $452{ }^{\circ} \mathrm{C}$ and $446{ }^{\circ} \mathrm{C}$, respectively for alloy $\mathrm{M} 5$, which fall in the similar range observed by DSC in Fig. 6, confirming the formation of these phases in alloys with relatively high $\mathrm{Mg}$ content, as shown in Figs. 3b, 4e and 5d. Besides, it is found that the peak formation of $\mathrm{Mg}_{2} \mathrm{Si}$ (Peak 2) shifts from $587{ }^{\circ} \mathrm{C}$ in $\mathrm{M} 2$ to $558{ }^{\circ} \mathrm{C}$ in $\mathrm{M} 5$. In addition, the formation temperature of Fe-intermetallic (Peak 3) is also different in two alloy, confirming the different dominant Fe-intermetallic in M2 and M5 (Fig. 3 and Fig. 6). In addition, the formation temperature of $\alpha$-Al also changes from $647^{\circ} \mathrm{C}$ in $\mathrm{M} 2$ to 631 ${ }^{\circ} \mathrm{C}$ in M5, which is corresponding to the Scheil simulation (Fig. 1b and Fig. 1c)

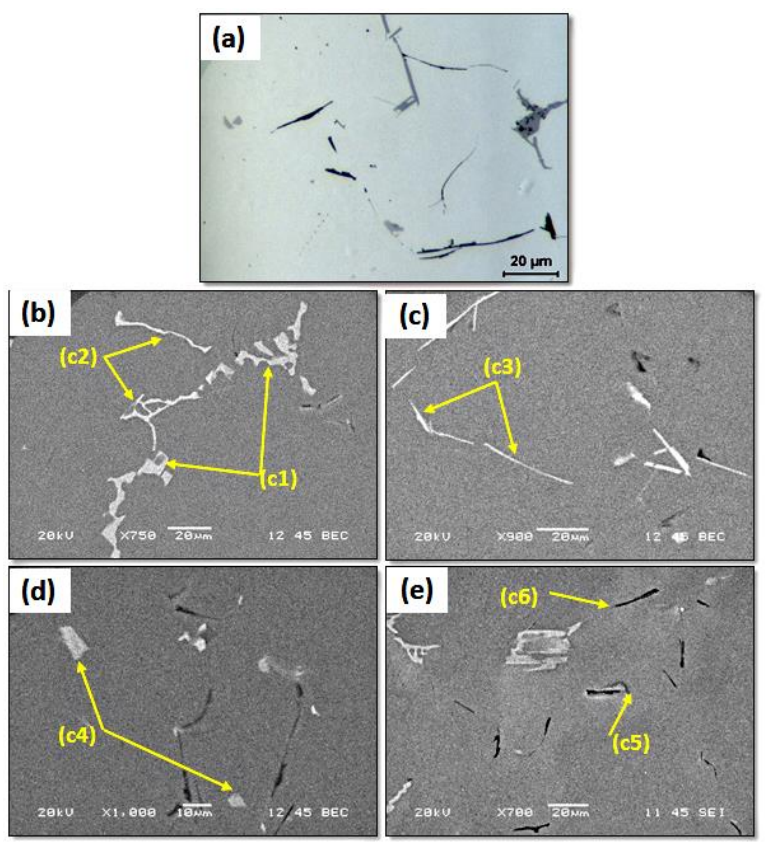

Fig. 5. Optical micrograph (a) and SEM images (b-e) showing different intermetallic phases in M4 alloy.

As shown in Figs. 2-6, the various intermetallic phases in alloys with different $\mathrm{Mg}$ levels have been studied and identified based on the color contrast, morphology and chemical composition (Table 2). Due to some similarities on the chemical composition and the morphology of intermetallic phases, especially on the Fe-rich phases, hence, the Fe-rich phases have been further confirmed by EBSD, which is based on the crystal structure of phase. As shown in Table 3, the various Fe-rich phases exhibit different crystal structure and lattice parameter [13], and therefore, collecting crystallography information from EBSD can improve the phase identification. As examples, the identification of Fe-rich phases in M4 and M5 alloys, in which the formation of Fe-rich is more complicated, are shown in Fig. 8 and 9. For each sample, more than 20 particles are randomly selected and measured.
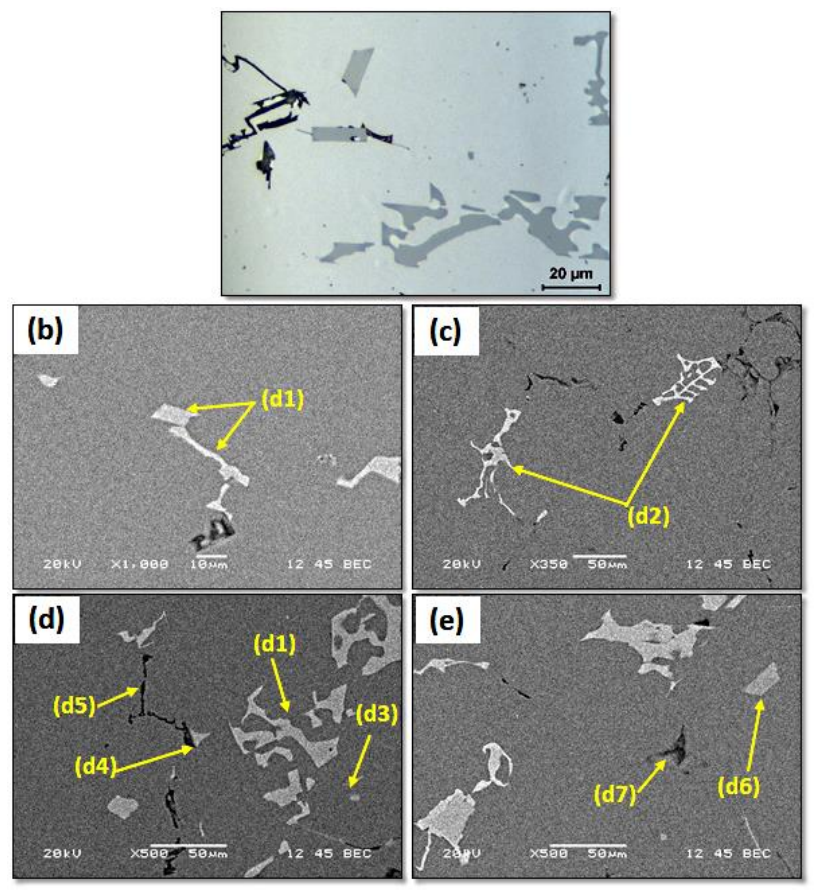

Fig. 6. Optical micrograph (a) and SEM Images (b-e) of M5 alloy showing various intermetallic phases.

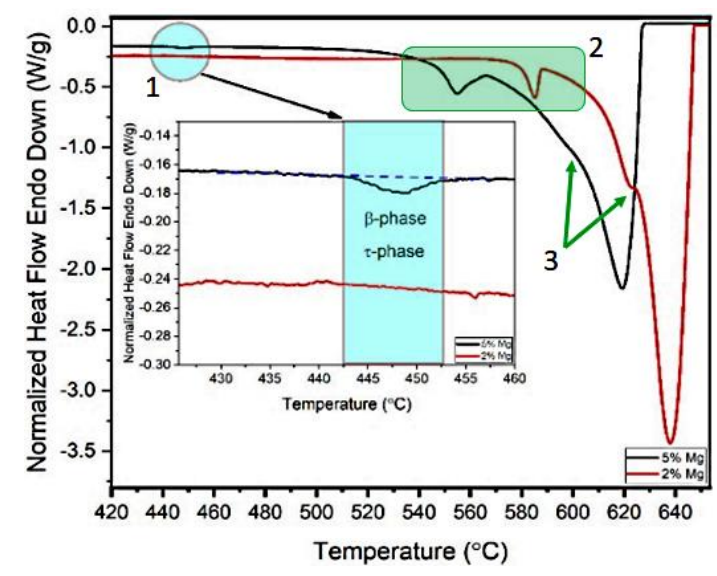

Fig. 7. DSC heating curves for two experimental alloy with different $\mathrm{Mg}$ levels, showing the formation of $\beta$-phase in the temperature range $443-450^{\circ} \mathrm{C}$ 
Table 2. SEM-EDS results for various intermetallic phases found in as-cast microstructure of experimental alloys

\begin{tabular}{|c|c|c|c|c|c|c|c|c|c|c|}
\hline \multirow{2}{*}{$\begin{array}{c}\text { Alloy } \\
\text { ID }\end{array}$} & \multirow{2}{*}{\multicolumn{2}{|c|}{ Intermetallic phases }} & \multicolumn{8}{|c|}{ Element, wt.\% } \\
\hline & & & Mn & $\mathrm{Fe}$ & $\mathbf{S i}$ & Mg & $\mathbf{C u}$ & $\mathrm{Cr}$ & $\mathbf{T i}$ & Al \\
\hline \multirow{3}{*}{ M2 } & al & $\mathrm{Al}(\mathrm{E}-\mathrm{Mn}) \mathrm{C}$ & 10.3 & 13.8 & 5.9 & 0 & 0 & 1.6 & 0 & 78.9 \\
\hline & $\mathrm{a} 2-$ & & 7.8 & 11.4 & 5.8 & 0 & 0 & 0 & 0 & 83.6 \\
\hline & a3 & $\mathrm{Mg}_{2} \mathrm{Si}$ & 0 & 0 & 0 & 20.2 & 16.3 & 0 & 0 & 63.5 \\
\hline \multirow{3}{*}{ M3 } & b1 & $\alpha-\mathrm{Al}(\mathrm{Fe}, \mathrm{Mn}) \mathrm{Si}$ & 8.3 & 8.9 & 5.2 & 1.2 & 0 & 0 & 0 & 76.3 \\
\hline & b3 & $\tau-\mathrm{Al}_{6} \mathrm{CuMg}_{4}$ & 0 & 0 & 0 & 23 & 16.7 & 0 & 0 & 60.3 \\
\hline & $\mathrm{b} 2$ & $\mathrm{Mg}_{2} \mathrm{Si}$ & 0 & 0 & 3.7 & 10.3 & 0 & 0 & 0 & 86.1 \\
\hline \multirow{6}{*}{ M4 } & $\mathrm{c} 1$ & $\mathrm{Al}_{6}(\mathrm{Mn}, \mathrm{Fe})$ & 11.4 & 11.3 & 0 & 0 & 0 & 0 & 0 & 77.3 \\
\hline & $\mathrm{c} 2$ & $\alpha-\mathrm{Al}(\mathrm{Fe}, \mathrm{Mn}) \mathrm{Si}$ & 9.7 & 11.4 & 4.01 & 1.3 & 0 & 0 & 0 & 73.5 \\
\hline & $\mathrm{c} 3$ & $\mathrm{Al}_{3}(\mathrm{Fe}, \mathrm{Mn})$ & 9.2 & 8.9 & 0 & 3.2 & 0 & 0 & 0 & 78.7 \\
\hline & $\mathrm{c} 4$ & $\varepsilon-\mathrm{Al}_{18}(\mathrm{Cr}, \mathrm{Mn})_{2} \mathrm{Mg}_{3}$ & 5.2 & 0 & 0 & 10.1 & 0 & 6.7 & 0 & 78.1 \\
\hline & $\mathrm{c} 5$ & $\tau-\mathrm{Al}_{6} \mathrm{CuMg}_{4}$ & 0 & 0 & 0 & 17.8 & 9.5 & 0 & 0 & 72.7 \\
\hline & c6 & $\mathrm{Mg}_{2} \mathrm{si}$ & 0 & 0 & 4 & 11.4 & 0 & 0 & 0 & 84.6 \\
\hline \multirow{8}{*}{ M5 } & & $\boldsymbol{\nabla}_{\mathrm{m}}(\mathrm{Fe}, \mathrm{Mn})$ & 8.9 & 12.1 & 0 & 0 & 0 & 0 & 0 & 79.0 \\
\hline & $\mathrm{d} 1$ & $\rightarrow \mathrm{Al}_{6}(\mathrm{Mn}, \mathrm{Fe})$ & 11.6 & 11.4 & 0 & 0 & 0 & 0 & 0 & 77.1 \\
\hline & $\mathrm{d} 2$ & $\alpha-\mathrm{Al}(\mathrm{Fe}, \mathrm{Mn}) \mathrm{Si}$ & 11.6 & 11.2 & 4.4 & 0 & 0 & 0 & 0 & 72.8 \\
\hline & $\mathrm{d} 3$ & $\varepsilon-\mathrm{Al}_{18}(\mathrm{Cr}, \mathrm{Mn})_{2} \mathrm{Mg}_{3}$ & 11.3 & 0 & 0 & 11.1 & 0 & 4.6 & 0 & 73 \\
\hline & $\mathrm{d} 4$ & $\tau-\mathrm{Al}_{6} \mathrm{CuMg}_{4}$ & 0 & 0 & 0 & 20.5 & 12.9 & 0 & 0 & 66.6 \\
\hline & $\mathrm{d} 5$ & $\mathrm{Mg}_{2} \mathrm{Si}$ & 0 & 0 & 15.8 & 18.4 & 0 & 0 & 0 & 65.8 \\
\hline & d6 & $\mathrm{Al}_{7}(\mathrm{Cr}, \mathrm{Ti})$ & 0 & 0 & 0 & 11.0 & 0 & 7.9 & 5.8 & 75.2 \\
\hline & $\mathrm{d} 7$ & $\beta-\mathrm{Al}_{5} \mathrm{Mg}_{3}$ & 0 & 0 & 0 & 13.3 & 0 & 0 & 0 & 86.8 \\
\hline
\end{tabular}

Table 3 Crystallographic information of iron-rich intermetallics [13]

\begin{tabular}{c|c|c}
\hline Phases & Crystal structure & Crystal parameters \\
\hline$\alpha-\mathrm{Fe}$ & body-centered cubic & $\mathrm{a}=\mathrm{b}=\mathrm{c}=1.265 \mathrm{~nm}$ \\
$\beta-\mathrm{Fe}$ & tetragonal & $\mathrm{a}=0.643 \mathrm{~nm}, \mathrm{~b}=0.746 \mathrm{~nm}, \mathrm{c}=0.878 \mathrm{~nm}$ \\
$\mathrm{Al}_{6} \mathrm{Fe}$ & Orthorhombic & $\mathrm{a}=0.643 \mathrm{~nm}, \mathrm{~b}=0.746 \mathrm{~nm}, \mathrm{c}=0.878 \mathrm{~nm}$ \\
$\mathrm{Al}_{\mathrm{m}} \mathrm{Fe}$ & body-centered tetragonal & $\mathrm{a}=\mathrm{b}=0.884 \mathrm{~nm}, \mathrm{c}=2.16 \mathrm{~nm}$ \\
$\mathrm{Al}_{3} \mathrm{Fe}$ & Monoclinic & $\mathrm{a}=1.549 \mathrm{~nm}, \mathrm{~b}=0.808 \mathrm{~nm}, \mathrm{c}=1.248 \mathrm{~nm}$ \\
\hline
\end{tabular}


Figs. 8 and 9 display the typical Fe-rich intermetallic phases found in M4 and M5 alloys with their corresponding patterns and simulated results. The mean angular deviation (MAD) between the experimental and calculated patterns indicates the accuracy of the solution given by the software (Channel 5), in which a smaller value of MAD means a higher accuracy between the experimental and simulated patterns. For a desirable accurate solution, the MAD value should be at least lowly than 0.7 .

As shown in Fig. 8 (a1, a2 and a3), the MAD values for $\alpha-\mathrm{Al}(\mathrm{Fe}, \mathrm{Mn}) \mathrm{Si}, \mathrm{Al}_{6}(\mathrm{Mn}, \mathrm{Fe})$ and $\mathrm{Al}_{3}(\mathrm{Mn}, \mathrm{Fe})$ are 0.351 , 0.446 and 0.115 , respectively, which is much lower than the critical value 0.7. Consequently, those three Fe-rich intermetallic phases in M4 alloy have been confirmed with the combined use of EBSD and SEM-EDS. Similarly, the formation of three Fe-rich intermetallics in M5 alloy, e.g. $\mathrm{Al}_{6}(\mathrm{Mn}, \mathrm{Fe}), \mathrm{Al}_{\mathrm{m}}(\mathrm{Mn}, \mathrm{Fe})$ and $\alpha-\mathrm{Al}(\mathrm{Fe}, \mathrm{Mn})$, have also been confirmed by EBSD analysis with low MAD values, as shown in Fig. 9 (b1, b2 and b3).
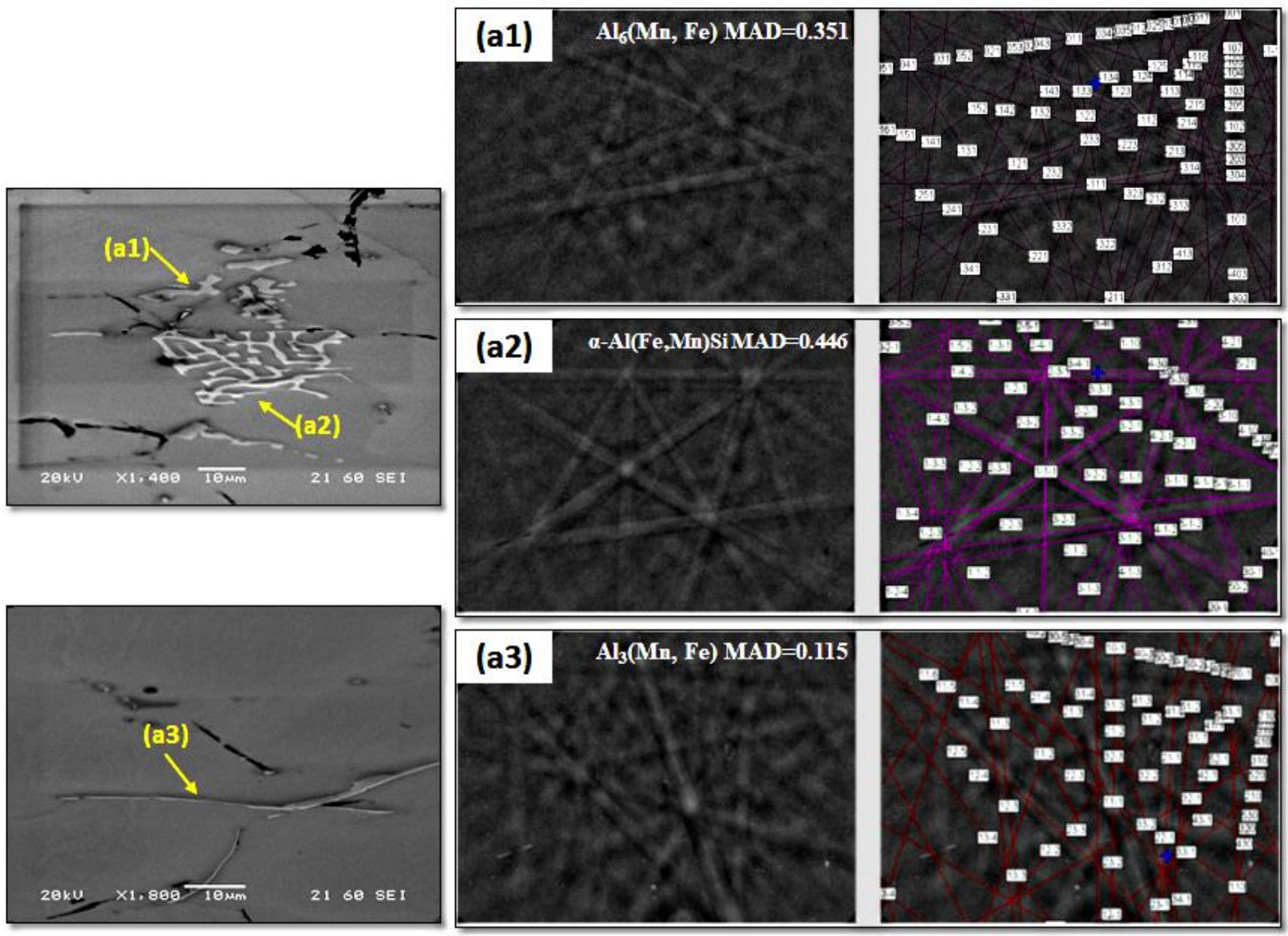

Fig. 8. SEM Micrographs and EBSD patterns of M4 alloy showing different intermetallic phases with corresponding patterns and simulated results

\subsection{Discussion}

As shown in Figs. 2-7 from the SEM and EBSD analysis (Figs. 8-9), it is confirmed that $\mathrm{Al}_{6} \mathrm{Mn}, \mathrm{Al}_{\mathrm{m}} \mathrm{Fe}, \alpha-$ $\mathrm{Al}(\mathrm{Fe}, \mathrm{Mn}) \mathrm{Si}$ and $\mathrm{Al}_{3} \mathrm{Fe}$ are the common Fe-rich phases present in the experimental $\mathrm{Al}-\mathrm{Mg}-\mathrm{Mn}$ alloys with various $\mathrm{Mg}$ levels. Generally, the solidification rate and chemical composition will have important influence on the as-cast microstructure. For instance, the higher solidification velocity and the presence of grain refinement help the formation of the metastable $\mathrm{Al}_{\mathrm{m}} \mathrm{Fe}$ and $\mathrm{Al}_{6} \mathrm{Fe}$ phases over $\mathrm{Al}_{3} \mathrm{Fe}[11,12]$. In the present study, all the samples were taken from the center of the ingot where the solidification rate is almost the same. 
Therefore, the formation of various intermetallic in experimental alloys is likely to be attributed to the chemical composition, especially the $\mathrm{Mg}$ levels. In the as-cast microstructure, the $\alpha-\mathrm{Al}(\mathrm{Fe}, \mathrm{Mn}) \mathrm{Si}$ becomes a dominant phase in the low $\mathrm{Mg}$ alloys (M2 and $\mathrm{M} 3$ ), while $\mathrm{Al}_{6} \mathrm{Mn}$, $\mathrm{Al}_{3} \mathrm{Fe}, \alpha-\mathrm{Al}(\mathrm{Fe}, \mathrm{Mn}) \mathrm{Si}$ are the common Fe-rich phases with increasing the $\mathrm{Mg}$ level in M4 alloy.
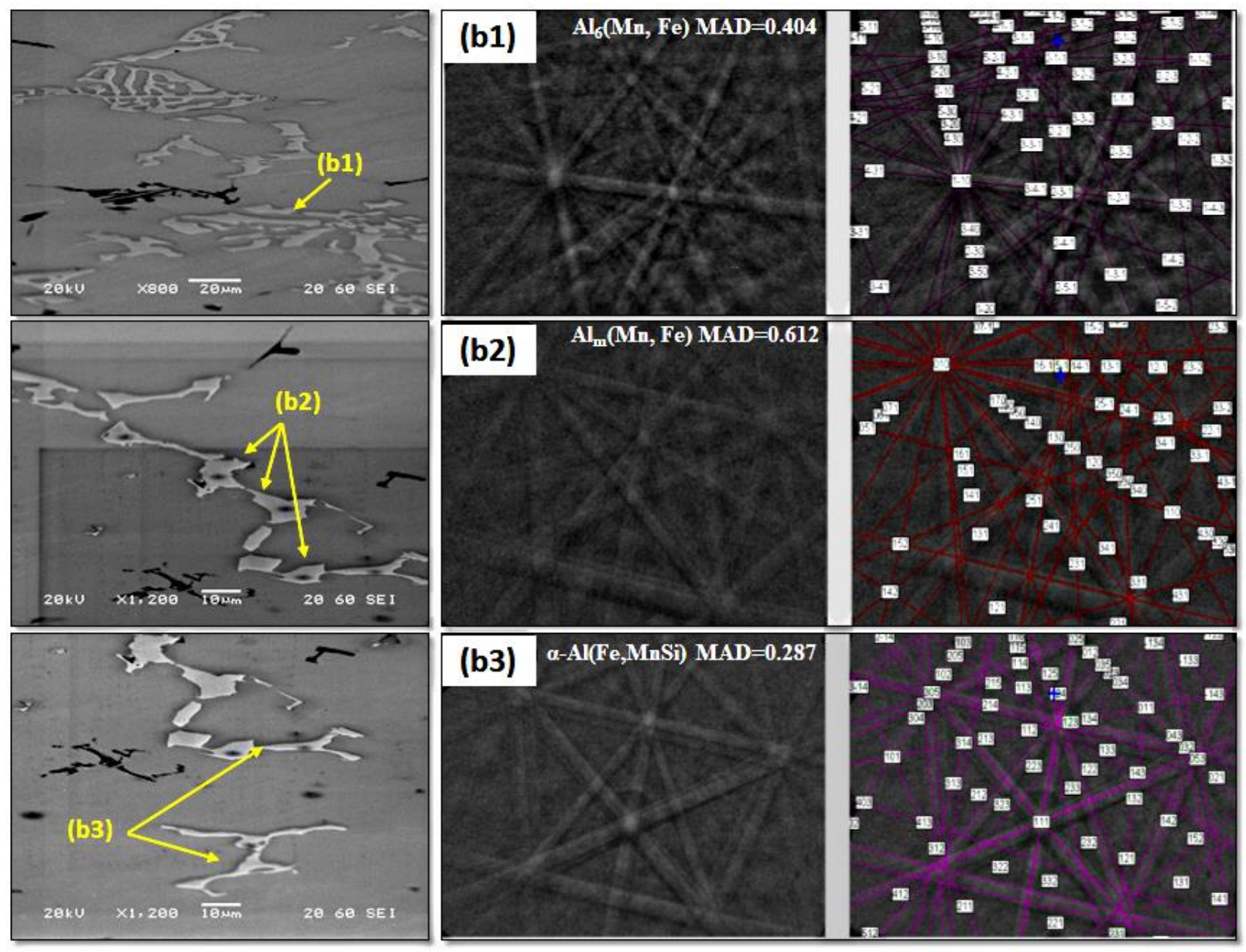

Fig. 9. SEM Micrographs and EBSD patterns of M5 alloy showing different intermetallic phases with corresponding patterns and simulated results.

Further increase in $\mathrm{Mg}$ content in $\mathrm{M} 5$ alloy, $\mathrm{Al}_{6} \mathrm{Mn}$ become the major iron-rich phases in addition to a minor fraction of $\mathrm{Al}_{\mathrm{m}} \mathrm{Fe}$ and $\alpha-\mathrm{Al}(\mathrm{Fe}, \mathrm{Mn}) \mathrm{Si}$, which could be related to $\mathrm{Mg}$ content and the $\mathrm{Si} / \mathrm{Mg}$ ratio.

In addition, it is also observed the morphology of primary $\mathrm{Mg}_{2} \mathrm{Si}$ changed from well-branched to flake-like shape by increasing the $\mathrm{Mg}$ content, which may be due to the solidification behavior of the experimental alloys. As shown in Fig. 7 and Figs. 1b\&c, increasing Mg content shifts the formation temperature of eutectic phases toward lower value, which can affect the growth rate, and the concentration of primary $\mathrm{Mg}_{2} \mathrm{Si}$.
A comparison on the formation of various intermetallic phases from Scheil simulation and real as-cast microstructure is provided in Table 4. In general, the results of Scheil simulation give an appropriate sequence of different intermetallic formed during solidification, in which Fe-rich intermetallic phases with different types precipitate first followed by $\mathrm{Mg}_{2} \mathrm{Si}$ and finally with the low meting point eutectic phases.

As shown in Table 4, the Scheil simulations predicted that $\mathrm{Al}_{6} \mathrm{Mn}$ is the major intermetallic phase for M2 and M3 alloys in addition to two minor Fe-rich phases of $\alpha$ $\mathrm{Al}(\mathrm{Fe}, \mathrm{Mn}) \mathrm{Si}$ and $\mathrm{Al}_{3} \mathrm{Fe}$, while $\alpha-\mathrm{Al}(\mathrm{Fe}, \mathrm{Mn}) \mathrm{Si}$ was found to 
be the dominant Fe-rich intermetallic phase in experimental as-cast microstructure. It is reported that the higher Si level in $\mathrm{Al}-\mathrm{Mg}$ alloys encourage the transformation of the Fe-rich intermetallic from $\mathrm{Al}_{6}(\mathrm{Fe}, \mathrm{Mn})$ to $\alpha-\mathrm{Al}(\mathrm{Fe}, \mathrm{Mn}) \mathrm{Si}$ [9], suggesting that a relatively high $\mathrm{Si} / \mathrm{Mg}$ ratio in low $\mathrm{Mg}$ alloys (M2 and M3) promotes the formation of $\alpha$ $\mathrm{Al}(\mathrm{Fe}, \mathrm{Mn}) \mathrm{Si}$ over $\mathrm{Al}_{6} \mathrm{Mn}$. On the other hand, the Scheil model predicted that $\mathrm{Al}_{6}(\mathrm{Fe}, \mathrm{Mn})$ is the major intermetallic phase with a minor $\mathrm{Al}_{3} \mathrm{Fe}$ intermetallic in the high $\mathrm{Mg}$ alloys
(M4 and M5), which is in a good agreement with the microscopic observation of as-cast microstructure in the corresponding two experimental alloys. The low $\mathrm{Si} / \mathrm{Mg}$ ratio in combination of high $\mathrm{Mn}$ might stabilize the formation of $\mathrm{Al}_{6}(\mathrm{Fe}, \mathrm{Mn})$ over $\mathrm{Al}_{3} \mathrm{Fe}$. The presence of a minor $\mathrm{Al}_{\mathrm{m}} \mathrm{Fe}$ in the as-cast microstructure of M5 alloy may be related to the higher $\mathrm{Mg}$ content or the presence of $\mathrm{TiB}_{2}$ in the grain refiner, which act as a heterogeneous nucleation site for $\mathrm{Al}_{\mathrm{m}} \mathrm{Fe}$ particles [5, 14-15].

Table 4 Summary and comparison on various intermetallic phases from Scheil simulation and real as-cast microstructure

\begin{tabular}{|c|c|c|c|c|}
\hline \multirow{2}{*}{ Alloy } & \multicolumn{2}{|c|}{ Scheil simulation } & \multicolumn{2}{|c|}{ Experimental } \\
\hline & Majority & Minority & Majority & Minority \\
\hline M2 & $\mathrm{Al}_{6} \mathrm{Mn}$ & $\begin{array}{c}\alpha-\mathrm{Al}(\mathrm{Fe}, \mathrm{Mn}) \mathrm{Si}\left(\mathrm{Al}_{15} \mathrm{Si}_{2} \mathrm{M}_{4}\right) \\
\mathrm{Al}_{3} \mathrm{Fe}\left(\mathrm{Al}_{13} \mathrm{Fe}_{4}\right) \\
\mathrm{Mg}_{2} \mathrm{Si} \\
\tau \text {-phase }\end{array}$ & $\alpha-\mathrm{Al}(\mathrm{Fe}, \mathrm{Mn}) \mathrm{Si}$ & $\mathrm{Mg}_{2} \mathrm{Si}$ \\
\hline M3 & $\mathrm{Al}_{6} \mathrm{Mn}$ & $\begin{array}{c}\mathrm{Al}_{3} \mathrm{Fe}\left(\mathrm{Al}_{13} \mathrm{Fe}_{4}\right) \\
\mathrm{Mg}_{2} \mathrm{Si} \\
\beta \text {-phase } \\
\tau \text {-phase }\end{array}$ & $\alpha-\mathrm{Al}(\mathrm{Fe}, \mathrm{Mn}) \mathrm{Si}$ & $\begin{array}{c}\mathrm{Mg}_{2} \mathrm{Si} \\
\tau \text {-phase }\end{array}$ \\
\hline M4 & $\mathrm{Al}_{6} \mathrm{Mn}$ & $\begin{array}{c}\mathrm{Al}_{3} \mathrm{Fe}\left(\mathrm{Al}_{13} \mathrm{Fe}_{4}\right) \\
\mathrm{Mg}_{2} \mathrm{Si} \\
\beta \text {-phase } \\
\tau \text {-phase } \\
\end{array}$ & $\begin{array}{l}\mathrm{Al}_{6}(\mathrm{Fe}, \mathrm{Mn}) \\
\mathrm{Al}_{3}(\mathrm{Fe}, \mathrm{Mn})\end{array}$ & $\begin{array}{c}\alpha-\mathrm{Al}(\mathrm{Fe}, \mathrm{Mn}) \mathrm{Si} \\
\mathrm{Mg}_{2} \mathrm{Si} \\
\varepsilon \text {-phase } \\
\tau \text {-phase }\end{array}$ \\
\hline M5 & $\mathrm{Al}_{6} \mathrm{Mn}$ & $\begin{array}{c}\mathrm{Al}_{3} \mathrm{Fe}\left(\mathrm{Al}_{13} \mathrm{Fe}_{4}\right) \\
\mathrm{Mg}_{2} \mathrm{Si} \\
\beta \text {-phase } \\
\tau \text {-phase }\end{array}$ & $\mathrm{Al}_{6} \mathrm{Mn}$ & $\begin{array}{c}\mathrm{Al}_{7}(\mathrm{Cr}, \mathrm{Ti}) \\
\alpha-\mathrm{Al}(\mathrm{Fe}, \mathrm{Mn}) \mathrm{Si} \\
\mathrm{Al}_{\mathrm{m}} \mathrm{Fe} \\
\mathrm{Mg}_{2} \mathrm{Si} \\
\varepsilon \text {-phase } \\
\tau \text {-phase } \\
\beta \text {-phase }\end{array}$ \\
\hline
\end{tabular}

\section{Conclusions}

1) Intermetallic phases formed during solidification were identified using SEM-EDS and EBSD techniques in the present work. $\mathrm{Al}_{6}(\mathrm{Mn}, \mathrm{Fe}), \quad \alpha-\mathrm{Al}(\mathrm{Fe}, \mathrm{Mn}) \mathrm{Si}, \quad \mathrm{Al}_{3} \mathrm{Fe}$, $\mathrm{Al}_{\mathrm{m}}(\mathrm{Mn}, \mathrm{Fe})$ and $\mathrm{Mg}_{2} \mathrm{Si}$ are the most common intermetallic phases in the as-cast microstructure of Al$\mathrm{Mg}-\mathrm{Mn}$ alloys depending on the $\mathrm{Mg}$ levels.

2) $\alpha-\mathrm{Al}(\mathrm{Fe}, \mathrm{Mn}) \mathrm{Si}$ with Chinese script morphology is the dominant Fe-rich intermetallic phase for the alloys containing 2-3 wt.\% Mg, while the major intermetallic phases are $\mathrm{Al}_{6}(\mathrm{Mn}, \mathrm{Fe})$ with blocky morphology and $\mathrm{Al}_{3}(\mathrm{Mn}, \mathrm{Fe})$ with needle-like morphology in the alloy containing $4 \mathrm{wt} . \% \mathrm{Mg}$. Further increasing Mg content to 5 wt. $\%, \mathrm{Al}_{6}(\mathrm{Mn}, \mathrm{Fe})$ becomes the dominant intermetallic phase with a minor $\mathrm{Al}_{\mathrm{m}}(\mathrm{Mn}, \mathrm{Fe})$ phase.
3) Two low melting point eutectic phases of $\beta-\mathrm{Al}_{3} \mathrm{Mg}_{2}$ and $\tau-\mathrm{Al}_{6} \mathrm{CuMg}_{4}$ are observed in the alloys with 3-5 wt. \% $\mathrm{Mg}$.

4) The morphology of $\mathrm{Mg}_{2} \mathrm{Si}$ change from well-branched to plate-like morphology by increasing the $\mathrm{Mg}$ contents.

5) The comparison on the formation of various intermetallic phases from Scheil simulation and real ascast microstructure is provided.

The authors would like to acknowledge the financial support of the Natural Sciences and Engineering Research Council of Canada (NSERC) and Rio Tinto Aluminum for their financial support through the Research Chair in the Metallurgy of Aluminum Transformation at University of Quebec in Chicoutimi. 


\section{References}

1. W. S. Miller, L. Zhuang, J. Bottema, A. J. Wittebrood, P. De Smet, A. Haszler, A. Vieregge, Mater. Sci. Eng. A, vol. 280, no. 1, pp. 37-49, (2000).

2. J. Kauman, ASM Int., Ch. 6, (2000).

3. L. Bäckerud, E. Król, J. Tamminen, vol. 2, pp. 113-123, (1986).

4. C. J. Simensen and U. Södervall, Surf. Interface Anal., vol. 30, no. 1, pp. 309-314, (2000).

5. Y. J. Li and L. Arnberg, Acta Mater., vol. 52, no. 9, pp. 2673-2681, 2004.

6. O. Engler and S. Miller-Jupp, J. Alloys Compd., vol. 689, pp. 998-1010, (2016).

7. O. Engler, K. Kuhnke, and J. Hasenclever, J. Alloys Compd., vol. 728, pp. 669-681, (2017).

8. O. Engler, Z. Liu, and K. Kuhnke, J. Alloys Compd., vol. 560, pp. 111-122, (2013).

9. Y. Liu, L. Luo, C. Han, L. Ou, J. Wang, and C. Liu, J. Mater. Sci. Technol., vol. 32, no. 4, pp. 305-312, (2016).
10. Z. F. Sundaram Kumar, H. B. Nadendla, G. M. Scamans, D. G. Eskin, stm media köthen, vol. 28, pp. 5-11, (2012).

11.Z. Zhang, G. Li X.-G. Chen, 13th International Conference on Aluminum Alloys. pp. 1857-1863, (2012).

12. C. M. Allen, K. A. Q. O'Reilly, B. Cantor, and P. V. Evans, Prog. Mater. Sci., vol. 43, no. 2, pp. 89-170, (1998).

13. K. Liu, X. Cao, X. G. Chen, Metall. and Mat. Trans. A, Phys. Metall. Mater. Sci, vol. 44, no 2, pp. 682-695, (2013).

14. W. T. Denholm, J. D. Esdaile, N. G. Siviour, and B. W. Wilson, Metall. Trans. A, Phys. Metall. Mater. Sci., vol. 18 A, no. 3, pp. 393-397, (1987).

15. M. W. Meredith, J. Worth, and R. G. Hamerton, Mater. Sci. Forum, vol. 396-402, no. 1, pp. 107-112, (2002). 